\title{
PENGEMBANGAN MEDIA INTERAKTIF BERBASIS STRATEGI PBL PADA MATA PELAJARAN PATTERN MAKING (MEMBUAT POLA) KELAS X BUSANA SMKN 8 MEDAN
}

\author{
Rahimah $^{1}$, R, Mursid ${ }^{2}$ \\ SMK Negeri 8 Medan, Teknologi Pendidikan Program Pascasarjana Universitas Negeri Medan \\ rahimah@yahoo.com, mursid.tp@gmail.com ${ }^{1}$
}

\begin{abstract}
Abstrak: Penelitian ini bertujuan untuk: (1) mengembangan media interaktif berbasis strategi PBLpadamata pelajaran Pattern Making;(2) mengetahui keefektifan media pembelajaran interaktif yang dikembangkan pada mata pelajaran Pattern Making dibandingkan dengan media grafis. Hasil penelitian dan pengembangan menunjukkan bahwa: (1) Produk Media interaktif pattern making dikemas dalam bentuk CD, (2) validasi para ahli secara umum menyatakan kualitas produk media iteraktifini termasuk dalam kriteria $84,78 \%$ dari rentang skor $1-5$,pengujian hipotesis produk media interaktif ini dinyatakan efektif digunakan untuk pembelajaran pattern making di mana terdapat perbedaan yang signifikan antara hasil belajar siswa kelas kontrol dan kelas eksperimen. Hasil pengolahan data dengan menggunakan uji t satu pihak diperoleh harga $t$ hitung seharga 2,85 lebih besar dari $\mathrm{t}_{\mathrm{t} \text { tabel }}$ seharga 2,00 maka dapat dinyatakan bahwa pengembangan media interaktif pembelajaran pattern making telah teruji efektif.
\end{abstract}

Kata Kunci: pengembangan media interaktif, strategi PBL, pattern making

Abstract: This study aimed to: (1) develop a strategy based interactive media PBLpadamata Pattern Making lessons; (2) determine the effectiveness of interactive learning media developed on the subjects of Pattern Making compared to graphic media. Research and development results show that: (1) Product pattern making interactive media packaged in a $C D$, (2) validation experts generally stated quality media products iteraktifini included in the criteria for $84.78 \%$ of the range of scores 1 to 5 , hypothesis testing products was declared effective interactive media is used for making the learning pattern where there are significant differences between the results of student learning and classroom control classroom experiment. The results of data processing using the $t$ test of the price obtained for $2.85 \mathrm{t}$ is greater than $\mathrm{t}$ table for 2.00 it can be stated that the development of interactive media learning pattern making has proven effective.

Keywords: development of interactive media, PBL strategy, pattern making

\section{PENDAHULUAN}

Keberhasilan peningkatan mutu sumber daya manusia melalui pendidikan tidak lepas dari kemampuan guru dalam mendesain suatu proses pembelajaran sehingga siswa memperoleh keterampilan dan nilai yang mencukupi standar nasional. Hal ini tentu saja membutuhkan guru yang mampu mengajar. Berkaitan dengan hal tersebut Hamalik (2001: 44) mengemukakan, mengajar dapat diartikan sebagai (1) menyampaikan pengetahuan kepada siswa, (2) mewariskan kebudayaan kepada generasi muda, (3) usaha mengorganisasi lingkungan sehingga menciptakan kondisi belajar bagi siswa, (4) memberikan bimbingan belajar kepada murid, (5) kegiatan mempersiapkan siswa untuk menjadi warga negara yang baik, (6)suatu proses membantu siswa menghadapi kehidupan masyarakat sehari-hari. Trianto (2010:17) "Pembelajaran merupakan aspek kegiatan manusia yang kompleks, yang tidak sepenuhnya dapat dijelaskan".Pembelajaran secara simpel dapat diartikan sebagai produk interaksi berkelanjutan antara pengembangan dan pengalaman hidup.Pembelajaran dalam makna kompleks adalah usaha sadar dari seorang guru untuk membelajarkan siswanya (mengarahkan interaksi siswa dengan sumber belajar lainnya) dalam rangka mencapai tujuan yang diharapkan. 
Berdasarkan hasil studi pendahuluan yang penulis peroleh di SMKN 8 Medan melalui pembagian angket kepada 27 guru menunjukkan bahwa $100 \%$ guru membutuhkan media pembelajaran interaktif dalam porses pembelajaran agar prosespembelajaran berjalan lebih efektif. Sebelumnya guru hanya menggunakan media buku dan papan tulis sebagai media, hanya beberapa materi tertentu yang menggunakan media interaktif.Hasil angket kepada guru diketahui bahwa kendala dalam menggunakan media interaktif adalah masih jarang sekali digunakan karena belum banyak guru yang memiliki keahlian untuk mengembangkan dan menggunakan multimedia interaktif, masih ada guru yang menyatakan tidak terbiasa dengan teknologi komputer. Sehingga proses pembelajaran dilaksanakan dengan seadanya (secara konvensional). Dari angket yang disebar kepada 32 orang siswa diambil sebagai sampel, $100 \%$ siswa menyatakan media interaktif sangat diperlukan karena pembelajaran jadi lebih menarik dan siswa dapat memanfaatkan media interaktif sebagai sarana pembelajaran individual.

Merujuk kepada perolehan hasil belajar di atas dan hasil observasi disimpulkan bahwa peran guru sebagai pendidik adalah sebagai penggiat dalam proses optimalisasi belajar siswa. Guru mempunyai peran utama untuk memanusiakan manusia, guru juga disebut sebagai peran penggiat karena dengan pertimbangan bahwa siswa adalah orang yang memiliki benih kodrati yang tidak terpisahkan dari lingkungan kehidupannya, maka guru hendaknya memiliki kemampuan dalam merencanakan dan menciptakan lingkungan belajar secara kondusif bagi siswa.Supriadi (2002:2) bahwa peran guru pada abad ke-21 diantaranya adalah "teacher as learners-who always improve and renew theori knowledge".Guru harus dapat menciptakan suatu pembelajaran yang berpotensi menciptakan suasana belajar mandiri, serta membawa kelas bagaikan magnet yang mampu memikat dan menarik siswa untuk belajar dalam suasana yang menyenangkan.

Munadi (2011:5) media pembelajaran dapat dipahami sebagai "segala sesuatu yang dapat menyampaikan dan menyalurkan pesan dari sumber secara terencana sehingga tercipta lingkunganbelajar yang kondusif dimana penerimanya dapat melalukan proses belajar secara efisien dan efektif". Dengan demikian, tujuan pemanfaatan media dalam proses pembelajaran adalah untuk mengefektifkan dan mengefisienkan proses pembelajaran itu sendiri.

Dari penjelasan tersebut, maka kehadiran media pembelajaran interaktif di sekolah saat ini merupakan hal yang berguna bagi proses pembelajaran. Pendapat perlunya penggunaan media interaktif dalam proses pembelajaran dikelas juga dikemukakan oleh Endi (2008:103) terdapat prestasi belajar yang signifikan setelah melaksanakan pembelajaran dengan media interaktif dibandingkan dengan prestasi belajar dengan media cetak.

Berdasarkan kenyataan tersebut, penulis menyadari pentingmya pengembangan media pembelajaran interaktif untuk mata pelajaran Membuat Pola (Pattern Making) di SMK. Dengan pengembangan media interaktif ini diharapkan dapat membantu guru dalam menjelaskan/menyajikan materi pelajaran yang lebih baik dan menarik bagi pebelajar, sehingga guru dan peserta didik tidak hanya bergantung pada buku pelajaran yang ada. Peserta didik sebagai penerima materi pelajaran akan lebih termotivasi dan mudah memahami materi yang disampaikan. Penelitian ini merupakan upaya untuk mengembangkan media pembelajaran interaktif untuk mata pelajaran Membuat Pola (Pattern Making) di SMK dengan Adobe Flash CS 6

Belajar merupakan salah satu faktor yang mempengaruhi dan berperan pentingdalam pembentukan pribadi dan perilaku individu. Nana Syaodih (2009:21) menyebutkan bahwa sebagian besar perkembangan individu berlangsung melalui kegiatan belajar. Sedangkan pengertian belajar menurut para ahli yaitu, Witherington dalam Sukmadinata (2005:1) berpendapat bahwa "belajar merupakan perubahan dalam kepribadian yang dimanifestasikan sebagai pola-pola respons yang baru berbentuk keterampilan, sikap, kebiasaan, pengetahuan dan kecakapan".

$$
\text { Selanjutnya }
$$

Crow\&Crow (Rusman,2012:7)menyatakan "belajar adalah diperolehnya kebiasaan-kebiasaan, pengetahuan dan sikap baru" .Sejalan dengan hal tersebut Hilgard mendefinisikan "belajar adalah proses di mana suatu perilaku muncul atau berubah karena adanya respons terhadap sesuatu situasi". Di Vesta dan Thompson seperti dikutip (Riyana, (2012: 7) menyatakan " belajar adalah 
perubahan perilaku yang relatif menetap sebagai hasil dari pengalaman".

Dengan demikian hasil belajar

Membuat Pola (pattern making) adalah bentuk penguasaan kategori hasil belajar seperti dikemukakan Bloom dalam Anderson (2001:

67) yang mengklasifikasi hasil belajar dalam 3 ranah yaitu ranah kognitif, ranah afektif danranah psikomotorik. Ranah kognitif berhubungan dengan berfikir yang terdiri dari 6 jenjang yaitu (1) ingatan, (2) pemahaman, (3) aplikasi, (4) analisis,(5) evaluasi, dan (6) kreatifitas. Ranah Afektif menyangkut aspek sikap dimana yang paling utama dalam kapasitas seseorang yang terdiri dari 5 jenjang yaitu: (1) penerimaan,(2) penanggapan (3) penghargaan, (4) pengorganisasian, dan (5) penjatidirian. Pada ranah psikomotorik, perubahan perilaku dalam ranah ini terdiri atas 4 jenjang yaitu (1) peniruan, (2) manipulasi,(3) artikulasi, dan (4) pengalamiahan.

Kegiatan pembelajaran merupakan interaksi antara siswa dan guru. Mengajar dapat diartikan sebagai suatu kegiatan atau aktivitas dalam rangka menciptakan suatu situasi dan kondisi belajar siswa yang kondusif. Menurut Sanjaya (2011: 101) "Mengajar dalam konteks standar pendidikan tidak hanya sekedar menyampaikan materi pelajaran, akan tetapi juga dimaknai sebagai proses mengatur lingkungan supaya siswa belajar. Pengaturan lingkungan adalah proses menciptakan iklim yang baik seperti penataan lingkungan, penyediaan alat dan sumber pembelajaran dan hal-hal lain yang memungkinkan siswa betah dan merasa senang belajar sehingga mereka dapat berkembang secara optimal sesuai dengan bakat, minat dan potensi yang dimiliki." Gerlac \& Ely (Arsyad, 2011: 3) menyatakan bahwa media apabila dipahami secara garis besar adalah manusia, materi atau kejadian yang membangun kondisi yang membuat siswa mampu memperoleh pengetahuan keterampilan atau sikap. Dengan kata lain guru, buku teks dan lingkungan sekolah merupakan media belajar untuk siswa.

Media adalah alat bantu apa saja yang dapat dijadikan sebagai penyalur pesan guna mencapai tujuan pengajaran (Djamarah, 2002: 137). Media pembelajaran adalah alat atau bentuk stimulus yang berfungsi untuk menyampaikan pesan pembelajaran, bentukbentuk stimulus sebagai media misalnya hubungan atau interaksi manusia, realia, gambar bergerak atau tulisan dan suara yang direkam (Rusman, 2011: 60). Menurut Hamidjoyo seperti dikutip (Latuheru:(1993:4) memberi batasan media sebagai semua bentuk perantara yang digunakan oleh manusia untuk menyampaikan atau menyebar ide, gagasan, atau pendapat sehingga ide, gagasan atau pendapat yang dikemukakan itu sampai ke pada penerima yang dituju.

Asyhar (2012:5) media memiliki peran yang sangat penting yaitu suatu sarana atau perangkat yang berfungsi sebagai perantara atau saluran dalam suatu proses komunikasi antara komunikator dan komunikan. Dalam hal ini komunikator dan komunikan yang dimaksud adalah guru dan siswa.Penggunaaan media dalam pembelajaran sangat membantu siswa agar bisa belajar dengan mudah tanpa ada batasan waktu dan tempat. Smaldino seperti dikutip (Putri (2012: 9) juga mengemukakan lima tipe dasar media, yaitu (1) text, yang dapat disajikan dalam berbagai format seperti buku, poster, papan tulis,layar komputer, dan sebagainya, (2) audio, termasuk didalamnya segala sesuatu yang dapat didengar seperti suara manusia, musik, suara mesin, dan sebagainya, (3) visual, termasuk diagram dalam poster, gambar dipapan tulis, foto, grafik di buku, kartun dan sebagainya, (4) manipulative, yaitu benda tiga dimensi yang dapat disentuh, dan (5) people, yaitu nara sumber seperti guru, siswa atau ahli bidang studi.

Seels \& Galsgow seperti dikutip (Arsyad, 2002: 36) menyatakan media pembelajaran interaktif adalah suatu sistem penyampaian pengajaran yang menyajikan materi video rekaman dengan pengendalian komputer kepada siswa yang tidak hanya mendengar dan melihat video dan suara tetapi juga memberikan respon yang aktif dan respon itu yang menentukan kecepatan dan sekuensi penyajian. Media pembelajaran dapat dikatakan interaktif apabila peserta didik tidak hanya melihat dan mendengar tetapi secara nyata berinteraksi langsung dengan media pembelajaran itu, peserta didik dilibatkan dalam penggunaan media pembelajaran. (Supriyadi, 2012: 8) Contoh multimedia interaktif adalah aplikasi game dan gambar bergerak. Sedangkan pembelajaran diartikan sebagai proses penciptaan lingkungan yang memungkinkan terjadinya proses belajar. Menurut Miarso 
(2005: 465) karakteristik terpenting media interaktif adalah bahwa siswa tidak hanya memperhatikan penyajian atau objek, tetapi "dipaksa" untuk berinteraksi selama mengikuti pelajaran.

Media tambahan lain biasanya digabungkan untuk format tutorial terprogram, seperti tugas-tugas bacaan berbasis cetak, kegiatan kelompok, percobaan laboratorium, kegiatan latihan, simulasi, dan interaktif dengan videodisc. Manfaat tutorial terprogram akan tampak jika menggunakan kemampuan teknologi komputer untuk bercabang dan interaktif. Keuntungan dengan pemanfaatan komputer sebagai media pendidikan menurut Arsyad (2011: 54-55) adalah: (1) komputer dapat mengakomodasikan siswa yang lambang menerima pelajaran, (2) komputer dapat merangsang siswa untuk mengerjakan latihan, kegiatan laboratorium atau simulasi, (3) kendali berada di tangan siswa sehingga tingkat kecepatan belajar siswa dapat disesuaikan dengan tingkat penguasaannya, (4) kemampuan merekam aktivitas siswa selama menggunakan suatu program pembelajaran memberi kesempatan lebih baik untuk pembelajaran secara perorangan dan perkembangan setiap siswa selalu dapat dipantau, (5) dapat berhubungan dengan, dan mengendalikan, peralatan lain seperti compact dics, video tape, dan lain-lain dengan program

Masalah pembelajaran merupakan masalah yang cukup kompleks dan banyak faktor yang mempengaruhinya, dua definisi yang dianut A. Chaedar Alwasilah dalam munadi (2013: 124) (1) "A relatively permanent change in respon potentiality wich occursas a result of reinforce practice" dan (2)A change in human disposition or capability, wich can be retained, an which is notsimply ascribable to the process of growth". Dari dua definisi ini ada 3 prinsip yang perlu diperhatikan. Pertama proses pembelajaran menghasilkan perubahan perilaku anak didik yang relatif permanen, tentunya dalam proses ini terdapat peran penggiat pembelajaran, yakni guru sebagai pelaku perubahan (agent of change). Kedua, anak didik memiliki potensi gandrung dan kemampuan yang merupakan benih kodrati untuk ditumbuh kembangkan tanpa henti. Guru berkewajiban untuk mengasah potensi siswa sehingga dengan optimalisasi potensi diri dicapailah kualitas siswa yang ideal. Ketiga, perubahan dan pencapaian kualitas ideal itu tidak tumbuh linear sejalan proses kehidupan. Artinya proses belajar mengajar itu memang merupakan bagian dari kehidupan itu sendiri, tetapi didesain secara khusus dan bertujuan demi tercapainya hasil pembelajaran dengan kualitas yang ideal.

Media pembelajaran interaktif berbasis komputer pada mata pelajaran Pattern Making perlu mengikuti karakteristik yang dimiliki programmed instruction menurut prinsipprinsip desain pembelajaran. Asri Budiningsih (2003:36) motivasi mengandung pengertian adanya dorongan, baik dari dalam maupun dari luar diri individu yang membuat siswa memiliki kemampuan untuk belajar. Dengan memberikan tujuan pembelajaran sebelum memulai materi mata pelajaran Pattern Making akan dapat memotivasi siswa apalagi bila dijelaskan pula manfaat untuk membangun harapan dalam diri siswa tentang hal-hal yang harus dikuasai setelah belajar.

Sudrajat (2008: 18) strategi pembelajaran adalah suatu kegiatan pembelajaran yang harus dikerjakan guru dan siswa agar tujuan pembelajaran dapat dicapai secara efektif dan efisien, bahwa dalam strtegi pembelajaran terkandung makna perencanaan. Artinya, bahwa strategi pada dasarnya masih bersifat konseptual tentang keputusan keputusan yang akan diambil dalam suatu pelaksanaan pembelajaran. Menurut Reigeluth (1999: 400) bahwa strategi pembelajaran sebagai metode-metode untuk memanipulasi unsur-unsur, bahan-bahan pengetahuan. Demikian pula Moore (2005: 450) berpendapat bahwa strategi pembelajaran merupakan keseluruhan perencanaan untuk mengajar pelajaran tertentu yang memuatkan metode dan urutan langkah-langkah yang diikuti untuk melaksanakan kegiatan belajar.

Seels dan Richey (1994: 87) menjelaskan bahwa strategi pembelajaran adalah spesifikasi untuk memilih dan mengurutkan kejadian dan aktivitas pembelajaran. Aktivitas pembelajaran meliputi penyajian materi, pemberian contoh, pemberian latihan serta pemberian umpan balik. Moejiono dan Dimyati (1999: 89) menjelaskan bahwa untuk mengoptimalkan interaksi antara siswa dengan komponen sistem pembelajaran lainnya, guru harus mengkonsistensikan tiap-tiap aspek dari komponen-komponen yang membentuk 
sistem tersebut, guru dapat melakukan hak tersebut Problem Based Learning merupakan suatu startegi pembelajaran yang melibatkan siswa untuk memecahkan masalah melalui tahap metode-metode ilmiah sehingga siswa dapat mempelajari pengetahuan yang berhubungan dengan masalah tersebut dan sekaligus memiliki keterampilan untuk memecahkan masalah (Kamdi, 2007: 77). PBL atau pembelajaran berbasis masalah adalah suatu pendekatan pembelajaran yang menggunakan masalah dunia nyata sebagai konteks bagi siswa. Untuk belajar tentang cara berpikir kritis dan memiliki keterampilan pemecahan masalah, serta untuk memperoleh pengetahuan dengan konsep yang esensisal dari materi pelajaran.

Strategi $P B L$ adalah strategi pembelajaran dengan pendekatan pembelajaran siswa pada masalah autentik sehingga siswa dapat menyusun pengetahuannya sendiri, menumbuh kembangkan keterampilan yang lebih tinggi dan inkuiri, memandirikan siswa dan meningkatkan kepercayaan diri sendiri (Arends dalam Abbas, 2000: 13). Pembelajaran berbasis masalah meliputi pengajuan pertanyaan atau masalah, memusatkan pada keterkaitan antar disiplin, penyelidikan autentik, kerjasama dan menghasilkan karya serta peragaan. Pembelajaran berbasis masalah tidak dirancang untuk membantu guru memberikan informasi sebanyak-banyaknya pada siswa. Pembelajaran berbasis masalah antara lain bertujuan untuk membantu siswa mengembangkan ketrampilan berfikir dan ketrampilan pemecahan masalah (Ibrahim, 2002: 5).

Pengajaran berbasis masalah menuntut siswa untuk menghasilkan produk tertentu dalam bentuk karya nyata atau artefak dan peragaan yang menjelaskan atau mewakili bentuk penyelesaian masalah yang mereka temukan. Produk itu dapat berupa transkip debat, laporan, strategi fisik, video atau program komputer (Nurhadi, 2003: 56) Pengajaran berbasis masalah dicirikan oleh siswa bekerja sama satu sama lain (paling sering secara berpasangan atau dalam kelompok kecil). Bekerja sama memberikan motivasi untuk secara berkelanjutan terlibat dalam tugastugas kompleks dan memperbanyak peluang untuk berbagi inkuiri dan dialog dan untuk mengembangkan keterampilan sosial dan keterampilan berfikir.

Menurut Suparman (2012: 82) pengembangan pembelajaran lebih menitikberatkan pada tujuannya yaitu memecahkan masalah belajar, meningkatkan kualitas kegiatan pembelajaran, atau menciptakan situasi kondisi belajar yang memungkinkan siswa berinteraksi sehingga terjadi perubahan perilaku melalui suatu proses yang meliputi desain, produksi, dan evaluasi. Prosesnya dimulai dengan mengidentifikasi masalah, mengembangkan strategi dan bahan pembelajaran

Metode ceramah adalah suatu cara penyajian bahan subjek dengan penuturan secara lisan yang sangat sesuai untuk memberikan informasi kepada siswa mengenai bahan subjek yang baru dan memberikan penjelasan tentang suatu masalah yang dihadapi siswa (Dhari, 1994 dalam Isjoni dan Ismail, 2008: 158-159). Sagala (2010: 201) menyatakan bahwa metode ceramah adalah sebuah bentuk interaksi melalui penerangan dan penuturan lisan dari guru kepada siswa.Metode ceramah sesuai digunakan untuk menyampaikan informasi kepada siswa. Djamarah (Isjoni dan Ismail, 2008: 158) berpendapat strategi pembelajaran konvensional atau disebut juga strategi ceramah adalah strategi yang digunakan sebagai alat komunikasi lisan antara guru dengan siswa dalam proses belajar mengajar yang ditandai dengan ceramah yang diiringi dengan penjelasan serta pembagian tugas dan latihan.

Rumusan masalah dalam penelitian ini sebagai berikut: (1) Bagaimanakah kualitas pengembanganmedia interaktif berbasis strategi $P B L$ pada mata pelajaran Pattern Making?: (2) Bagaimanakah efektifitas media pembelajaran interaktif yang dikembangkan pada mata pelajaran Pattern Makingdi bandingkandengan media grafis?

\section{METODE}

Penelitian ini dilaksanakan di SMKN 8 Medan Jalan DR. Mansyur, pada siswa kelas X Program Studi Tata Busana. Adapun langkahlangkah penelitian ini menggunakan dua tahap yakni tahap pertama untuk pengembangan media dalam menghasilkan produk dan tahap kedua menguji produk untuk melihat keefektifan dalam pembelajaran. Metode 
penelitian yang digunakan adalah research and development, karena penelitian ini termasuk penelitianpengembangan pendidikan yang dimaksudkan untuk menghasilkan produk pembelajaran yang layakdimanfaatkan dan sesuai kebutuhan. Borg dan Gall (1983: 772) memberikan batasan tentang penelitian sebagai usaha untuk mengembangkan dan memvalidasi produk-produk yang digunakan dalam pendidikan. Pengertian yang hampir sama dikemukakan oleh Asim (Waldopo: 2002: 91) bahwa penelitian pengembangan dalam pembelajaran adalah proses yang digunakan untuk mengembangkan dan memvalidasi produk - produk yang digunakan dalam proses pembelajaran.

Dari berbagai pendapat tersebut dapat ditarik kesimpulan bahwa metode yang digunakan dalam penelitian merupakan suatu jenis penelitian untuk menghasilkan produk produk bagi kepentingan pendidikan atau pembelajaran melalui pengembangan dan validasi produk - produknya diakhiri dengan evaluasi.

Analisisdata dalam penelitian ini menggunakan analisis deskriptif kuantitatif. Semua data yang terkumpul dianalisis dengan teknik statistik deskriptif yang secara kuantitatif dipisahkan menurut kategori untuk mempertajam penilaian dalam menarik kesimpulan. Data kualitatif yang berupa pernyataan sangat kurang baik, kurang baik, sedang, baik dan sangat baik diubah menjadi data kuantitatif dengan skala nilai 1 sampai 5.Hasilnya dirata-ratakan dan digunakan untuk menilai kualitas software pembelajaran. Kriteria software akan dikonversikan menjadi nilai dengan skala lima dengan menggunakan skala Linkert yang dianalisis secara deskriptif persentase dengan rumus sebagai berikut : $X$ $=\frac{\text { jumlah skor yang diperoleh }}{\text { jumlah skor ideal seluruh item }} \times 100 \%$ Dengan kriteria penilaian seperti yang tertulis pada tabel 1 berikut ini.

Tabel 1. Kriteria penilaian

\begin{tabular}{|c|c|c|}
\hline Nilai & Kriteria & Persentase \\
\hline A & Sangat baik & $81 \% \leq \mathrm{X} \leq 100 \%$ \\
\hline B & Baik & $61 \% \leq \mathrm{X} \leq 80 \%$ \\
\hline C & Sedang & $41 \% \leq \mathrm{X} \leq 60 \%$ \\
\hline
\end{tabular}

\begin{tabular}{|c|c|c|}
\hline D & Kurang baik & $21 \% \leq \mathrm{X} \leq 40 \%$ \\
\hline $\mathrm{E}$ & Sangat kurang baik & $0 \% \leq \mathrm{X} \leq 20 \%$ \\
\hline
\end{tabular}

Keterangan $\mathrm{X}=$ skor empiris

Apabila hasil yang diperoleh sudah mencapai kriteria minimal $61 \%$ maka multimedia pembelajaran intraktif ini dinyatakan sudah dapat dimanfaatkan dengan layak untuk proses pembelajaran pattern making.

Populasi dalam penelitian ini adalah seluruh siswa kelas $\mathrm{X}$ program studi tata busana SMKN 8 Medan yang berjumlah 141 orang. Sampel sebanyak dua kelas yaitu $X$ busana 1 sebagai kelas kontrol dengan jumlah siswa 34 orang dan kelas $\mathrm{X}$ busana 2 sebagai perlakuan/ eksperimen dengan jumlah siswa 34 orang. Sampel dalam penelitian ini adalah sebagian populasi.Siswa kelas $\mathrm{X}$ Busana 1 sebagai kelas kontrol dengan jumlah 34 orang dan kelas X Busana 2sebagai kelas eksperimen dengan jumlah siswa 34 orang

Tabel 2. Desain penelitian

Media Pembelajaran Interaktif Berbasis Multimedia Pada Mata Pelajaran Pattern Making

Menggunakan media $\quad$ Menggunakan pembelajaran interaktif media grafis (A2) (A1) $\mu \mathrm{A} 1$

Keterangan :

A1:Menggunakan media pembelajaran interaktif

A2 : Menggunakan media grafis

$\mu$ A1 : Hasil belajar Pattern Making menggunakan media pembelajaraninteraktif .

$\mu$ A2 : Hasil belajar Pattern Making menggunakan media grafis .

Pengujian hipotesis dilakukan dengan uji t satu pihak. Uji t satu pihak digunakan untuk mengetahui kesamaan hasil belajar siswa setelah diberikan perlakuan

Hipotesis yang diuji berbentuk :

Ho : $\mu_{1}=\mu_{2}$ : tidak ada perbedaan hasil belajar siswa yang menggunakan media interaktif dengan hasil belajar siswa yang menggunakan media grafis.

$\mathrm{H}_{\mathrm{a}}: \mu_{1}>\mu_{2}$ : ada perbedaan hasil belajar siswa yang menggunakan media 
interaktiflebih tinggi dengan siswa yang menggunakan media grafis.

Bila data penelitian berdistribusi normal dan homogen maka untuk menguji hipotesis menggunakan uji beda dengan rumus :

$$
\mathrm{t}_{\text {hitung }}=\frac{\overline{X_{1}}-\overline{X_{2}}}{S \sqrt{\left(\frac{1}{n_{2}}\right)+\left(\frac{1}{n_{2}}\right)}}
$$

Tetapi jika kedua kelas tidak homogen, maka digunakan :

$$
t^{\prime}=\frac{\overline{X_{1}}-\overline{X_{2}}}{S \sqrt{\frac{S_{1}^{2}}{n_{1}}+\frac{S_{2}^{2}}{n_{2}}}}
$$

Di mana $\mathrm{S}$ adalah varians gabungan yang dihitung dengan rumus yang dikemukakan oleh: $S^{2}=\frac{\left(n_{1}-1\right) S_{1}^{2}+\left(n_{2}-1\right) S_{2}^{2}}{n_{1}+n_{2}-2}$

Kriteria pengujian terima Ho jika $t_{1-1 / 2 \alpha}<t<t_{1-1 / 2 \alpha}$ dimana $t_{1}-1 / 2 \alpha$ didapat dari daftar distribusi $\mathrm{t}$ dengan $\mathrm{dk}=($ $\left.n_{1}+n_{2}-2\right)$ dan peluang $(1-1 / 2 \alpha)$ dan $\alpha=0,05$. Untuk harga $\mathrm{t}$ lainnya $\mathrm{Ho}$ ditolak.Untuk melihat nilai keefektifan, media pembelajaran interaktif yang dieksperimenkan digunakan rumus perhitungan efektifitas berikut

$$
=\frac{\text { jumlah skor yang diperoleh }}{\text { jumlah skor ideal seluruh item }} \times 100 \%
$$

Untuk menjawab Hipotesis penelitian dilakukan langkah berikut :

a. Dengan kriteria terima Ho jika$t_{1-1 / 2 \alpha}<t<t_{1-1 / 2 \alpha}$,jika nilai t memenuhi persamaan tersebut maka pengembangan media pembelajaran interaktif dikatakan tidak efektif namun bila harga t lainnya Ho ditolak terima $\mathrm{Ha}$ maka penelitian pengembangan media pembelajaran interaktif menunjukkan hasil efektif bagi mata pelajaran pattern making. Penentuan efektifitas berikutnya didapatkan .

b. Analisis keefektifan juga dapat disimpulkan perbandingan jumlah skor yang diperoleh dengan jumlah skor seluruh item dikali seratus persen, semakin besar persentase X, maka tingkat efektifitas media interaktif yang digunakan semakin baik.

\section{HASIL DAN PEMBAHASAN

\begin{tabular}{|c|c|c|c|c|c|c|c|c|}
\hline \multirow{2}{*}{ No } & \multirow{2}{*}{ Indikator penilaian } & \multicolumn{5}{|c|}{ Skor } & \multirow{2}{*}{$\begin{array}{l}\text { Presentase } \\
\text { isi materi } \\
\quad(\%)\end{array}$} & \multirow{2}{*}{ Kriteria } \\
\hline & & 1 & 2 & 3 & 4 & 5 & & \\
\hline 1 & Kejelasan judul program & & & & - & 30 & 100 & Sangat baik \\
\hline 2 & $\begin{array}{l}\text { Keejelasan penyajian petunjuk } \\
\text { belajar }\end{array}$ & & & & 2 & 28 & 93,2 & Sangat baik \\
\hline 3 & Keruntunan penyajian materi & & & & 3 & 27 & 89,9 & Sangat baik \\
\hline 4 & $\begin{array}{l}\text { Kemudahan dalam memahami } \\
\text { materi. }\end{array}$ & & & & 2 & 28 & 93,2 & Sangat baik \\
\hline 5 & $\begin{array}{l}\text { Materi dapat diulang setiap saat } \\
\text { sehingga meningkatkan daya } \\
\text { ingat. }\end{array}$ & & & & 3 & 27 & 89,9 & Sangat baik \\
\hline 6 & $\begin{array}{l}\text { Pemberian contoh video/ } \\
\text { gambar }\end{array}$ & & & & 3 & 26 & 86,5 & Sangat baik \\
\hline 7 & Terdapat soal-soal tes (evaluasi & & & & 3 & 27 & 89,9 & Sangat baik \\
\hline 8 & $\begin{array}{l}\text { Kejelasan petunjuk } \\
\text { mengerjakan tes ( evaluasi ) }\end{array}$ & & & & 2 & 28 & 93,2 & Sangat baik \\
\hline 9 & $\begin{array}{l}\text { Pemberian kesempatan } \\
\text { mengerjakan tes }\end{array}$ & & & & & 30 & 100 & Sangat baik \\
\hline
\end{tabular} \\ Hasil}

Tabel. 3. Skor Penilaian dan Tanggapan Media Pembelajaran Interaktif Uji Lapangan tentang kualitas Media Pembelajaran Aspek pembelajaran 


\begin{tabular}{|c|l|l|l|l|l|l|l|l|}
\hline 10 & $\begin{array}{l}\text { Feedback jawaban benar / salah } \\
\text { pada tes }\end{array}$ & & & & - & 30 & 100 & Sangat baik \\
\hline & & & & & & & 93,5 & Sangat baik \\
\hline
\end{tabular}

Tabel. 4. Skor Penilaian dan Tanggapan Media Pembelajaran Interaktif Uji Lapangan tentang

\begin{tabular}{|c|c|c|c|c|c|c|c|c|}
\hline \multirow{2}{*}{ No } & \multirow{2}{*}{ Indikator penilaian } & \multicolumn{5}{|c|}{ Skor } & \multirow{2}{*}{$\begin{array}{l}\text { Presentase } \\
\text { isi materi } \\
(\%)\end{array}$} & \multirow{2}{*}{ Kriteria } \\
\hline & & 1 & 2 & 3 & 4 & 5 & & \\
\hline 1 & $\begin{array}{l}\text { Kejelasan dalam penguraian } \\
\text { materi }\end{array}$ & & & & 1 & 29 & 96,5 & Sangat baik \\
\hline 2 & $\begin{array}{l}\text { Kesesuaian materi dengan } \\
\text { kebutuhan siswa }\end{array}$ & & & & - & 30 & 100 & Sangat baik \\
\hline 3 & $\begin{array}{l}\text { Kebermanfaatan materi } \\
\text { pembelajaran }\end{array}$ & & & & - & 30 & 100 & Sangat baik \\
\hline 4 & Faktualisasi isi materi & & & & 3 & 26 & 86,5 & Sangat baik \\
\hline 5 & $\begin{array}{l}\text { Kejelasan penggunaan bahasa } \\
\text { dalam materi }\end{array}$ & & & & 3 & 27 & 89,9 & Sangat baik \\
\hline 6 & $\begin{array}{l}\text { Kesesuaian bahasa dengan } \\
\text { sasaran pengguna }\end{array}$ & & & & 2 & 28 & 93,2 & Sangat baik \\
\hline 7 & $\begin{array}{l}\text { Kesesuaian gambar dalam } \\
\text { memperjelas materi }\end{array}$ & & & & 1 & 29 & 96,5 & Sangat baik \\
\hline 8 & $\begin{array}{l}\text { Ketepatan penggunaan video } \\
\text { dalam contoh }\end{array}$ & & & & 5 & 25 & 83,3 & Sangat baik \\
\hline 9 & $\begin{array}{l}\text { Ketepatan isi video dengan } \\
\text { materi }\end{array}$ & & & & 2 & 28 & 93,2 & Sangat baik \\
\hline 10 & $\begin{array}{l}\text { Kejelasan informasi dalam } \\
\text { ilustrasi video }\end{array}$ & & & & - & 30 & 100 & Sangat baik \\
\hline & & & & & & & $94 \%$ & Sangat baik \\
\hline
\end{tabular}

Tabel 5. Skor Penilaian dan Tanggapan Media Pembelajaran Interaktif Uji Lapangan tentang Kualitas Media Pembelajaran

\begin{tabular}{|c|c|c|c|c|c|c|c|c|}
\hline \multirow{2}{*}{ No } & \multirow{2}{*}{ Indikator penilaian } & \multicolumn{5}{|c|}{ Responden } & \multirow{2}{*}{$\begin{array}{l}\text { Presentase } \\
\text { isi materi } \\
(\%)\end{array}$} & \multirow[t]{2}{*}{ Kriteria } \\
\hline & & 1 & 2 & 3 & 4 & 5 & & \\
\hline 1 & Kemudahan pemakaian program & & & & 2 & 28 & 93,2 & Sangat baik \\
\hline 2 & $\begin{array}{l}\text { Kemudahan memilih menu } \\
\text { program }\end{array}$ & & & & 4 & 26 & 86,5 & Sangat baik \\
\hline 3 & $\begin{array}{l}\text { Kebebasan memilih materi untuk } \\
\text { dipelajari }\end{array}$ & & & & 5 & 25 & 83,3 & Sangat baik \\
\hline 4 & $\begin{array}{l}\text { Kemudahan berinteraksi denga } \\
\text { program }\end{array}$ & & & & 1 & 29 & 96,5 & Sangat baik \\
\hline 5 & Kemudahan ke luar dari program & & & & 1 & 29 & 96,5 & Sangat baik \\
\hline 6 & $\begin{array}{l}\text { Kecepatan fungsi tombol (kinerja } \\
\text { navigasi) }\end{array}$ & & & & 1 & 29 & 96,5 & Sangat baik \\
\hline 7 & $\begin{array}{l}\text { Kecepatan reaksi button (tombol } \\
\text { navigasi ) }\end{array}$ & & & & 2 & 28 & 93,2 & Sangat baik \\
\hline 8 & $\begin{array}{l}\text { Kemudahan pengaturan pencarian } \\
\text { halaman }\end{array}$ & & & & 2 & 28 & 93,2 & Sangat baik \\
\hline 9 & $\begin{array}{l}\text { Kemudahan pengaturan } \\
\text { menjalankan video }\end{array}$ & & & & 2 & 28 & 93,2 & Sangat baik \\
\hline
\end{tabular}




\begin{tabular}{|c|l|l|l|l|c|c|c|c|}
\hline $\mathbf{1 0}$ & Kompabilitas sistem operasi & & & & 5 & 25 & 83,3 & Sangat baik \\
\hline & & & & & & & $91,5 \%$ & Sangat baik \\
\hline
\end{tabular}

Tabel 6.Skor Penilaian dan Tanggapan Media Pembelajaran Interaktif Uji Lapangan tentang Kualitas Media Pembelajaran

\begin{tabular}{|c|l|c|c|c|c|c|c|c|}
\hline No & Indikator penilaian & \multicolumn{3}{|c|}{ Responden } & \multicolumn{2}{c|}{$\begin{array}{c}\text { Presentase isi } \\
\text { Materi ( \% ) }\end{array}$} & Kriteria \\
\cline { 2 - 7 } & & $\mathbf{1}$ & $\mathbf{2}$ & $\mathbf{3}$ & $\mathbf{4}$ & $\mathbf{5}$ & \\
\hline 1 & $\begin{array}{l}\text { Pemilihan jenis dan ukuran } \\
\text { huruf }\end{array}$ & & & & 2 & 28 & 93,2 & Sangat baik \\
\hline 2 & Keterbatasan teks dan tulisan & & & & - & 30 & 100 & Sangat baik \\
\hline 3 & $\begin{array}{l}\text { Kejelasan pemilihan warna } \\
\text { teks }\end{array}$ & & & & 3 & 27 & 89,9 & Sangat baik \\
\hline 4 & Kualitas tampilan & & & & 3 & 27 & 89,9 & Sangat baik \\
\hline 5 & Sajian animasi & & & & 2 & 28 & 93,2 & Sangat baik \\
\hline 6 & Kejelasan suara dan narasi & & & & 5 & 25 & 83,3 & Baik \\
\hline 7 & $\begin{array}{l}\text { Kemenarikan tampilan gambar } \\
\text { / contoh }\end{array}$ & & & & 1 & 29 & 96,5 & Sangat baik \\
\hline 8 & Kejelasan kualitas video & & & & 4 & 26 & 86,5 & Sangat baik \\
\hline 9 & Pemilihan backsound & & & & 5 & 25 & 83,3 & Baik \\
\hline 10 & Kesesuaian porsi warna & & & & 2 & 28 & 93,2 & Sangat baik \\
\hline & & & & & & & 90,9 & Sangat baik \\
\hline
\end{tabular}

Kesimpulan hasil penilaian dan tanggapan dari uji lapangan pada aspek pembelajaran, aspek materi, aspek pemrograman dan aspek tampilan muti media pada tabel 6 menunjukkan bahwa secara keseluruhan dalam kriteria $81 \%$ $\leq \mathrm{X} \leq 100 \%$ yaitu pada nilai rata-rata $92,40 \%$ maka kecenderungan penilaian penilaian uji lapangan di nyatakan kategori "Sangat Baik".

Adapun persentase rata-rata dari hasil penilaian para pengguna yaitu seperti yang terlihat pada Tabel 7.

Tabel.7. Persentase Rata-rata Hasil Penilaian Media Interaktif PembelajaranPattern Makingoleh Uji Coba Satu- Satu, Kelompok Kecil dan Uji Lapangan

\begin{tabular}{|l|l|c|l|}
\hline No. & $\begin{array}{c}\text { Para } \\
\text { pengguna }\end{array}$ & Persentase & Kriteria \\
\hline 1 & $\begin{array}{l}\text { Uji coba satu } \\
\text { - satu }\end{array}$ & $100 \%$ & $\begin{array}{l}\text { Sangat } \\
\text { Baik }\end{array}$ \\
\hline 2 & $\begin{array}{l}\text { Kelompok } \\
\text { kecil }\end{array}$ & $97.55 \%$ & $\begin{array}{l}\text { Sangat } \\
\text { baik }\end{array}$ \\
\hline 3 & Uji lapangan & $92,40 \%$ & $\begin{array}{l}\text { Sangat } \\
\text { baik }\end{array}$ \\
\hline \multicolumn{2}{|c|}{ Rata - rata } & $92,40 \%$ & $\begin{array}{l}\text { Sangat } \\
\text { baik }\end{array}$ \\
\hline
\end{tabular}

\section{Hasil Penelitian Uji Coba Keefektifan Produk}

Ho : $\mu_{1}=\mu_{2}$ : hasil belajar Pattern Making siswa yang mengggunakan media interaktif sama dengan siswa yang menggunakan media grafis.

Ha $: \mu_{1}>\mu_{2}$ : hasil belajar Pattern Makingsiswa yang menggunakan media interaktif lebih tinggi dari pada siswa yang menggunakan media grafis

Keterangan :

$\mu_{1}$ : rata-rata hasil belajar siswa yang menggunakan media interaktif

$\mu_{2}$ : rata-rata hasil belajar siswa yang menggunakan media grafis.

Ho : Tidak ada perbedaan hasil belajar siswa pada mata pelajaran pattern makingsesudah menggunakan media interaktif dari siswa sebelum menggunakan media interaktif.

Ha : Ada perbedaan hasil belajar siswa pada mata pelajaran pattern makingsesudah menggunakan media interaktif dari siswa sebelum menggunakan media grafis.

Hasil pengujian data dengan menggunakan uji t, data perhitungan selengkapnya terdapat pada lampiran 5 berdasarkan perhitungan yang dilakukan dihasilkan bahwa $t_{\text {hitung }}>t_{\text {tabel }}$ atau $2,85>2,00$, untuk $d k=62$. Hal ini berarti Ho di tolak danHa diterima dengan harga $t_{\text {hitung }}$ sebesar 13,79 maka dinyatakan hasil belajar siswa 
pada mata pelajaran Pattern Making dengan menggunakan media interaktif lebih tinggi dari hasil belajar siswa yang dibelajarkan dengan media grafis.Berarti Media Pembelajaran Interaktif pada mata palajaran Pattern Making dinyatakan telah teruji.

Keefektifan media interaktif diperoleh dengan cara sebagai berikut :

$X=\frac{\text { Jumlah Skor yang diperoleh }}{\text { jumlah skor ideal }}=\frac{2292}{3200} \times 100 \%$ $=71,62 \%$

Sedangkan keefektifan pembelajaran dengan media grafis adalah :
$X=\frac{\text { Jumlah Skor yang diperoleh }}{\text { jumlah skor ideal }}=\frac{2012}{3200} \times 100 \%$ $X=62,87 \%$

Dengan demikian nilai keefektifan media interaktif lebih tinggi dari nilai keefektifan pembelajaran dengan media grafis yaitu sebesar $8,75 \%$.

Hasil rangkuman persentase rata-rata hasil penilaian terhadap media interaktif pembelajaran Pattern Making oleh ahli materi, ahli desain instruksional, ahli media, uji coba perorangan, kelompok kecil dan kelas eksperimen/kelompok besar seperti yang terdapat pada Tabel 8 .

Tabel 8. Rangkuman Persentase Rata- rata Hasil Penilaian terhadap Produk Media Interaktif Pembelajaran Pattern Making.

\begin{tabular}{|l|l|c|l|}
\hline No. & \multicolumn{1}{|c|}{ Responden } & Persentase rata-rata & \multicolumn{1}{|c|}{ Kriteria } \\
\hline 1 & Ahli materi & $80,40 \%$ & Baik \\
\hline 2 & Ahli desain instruksional & $85,29 \%$ & Sangat baik \\
\hline 3 & Ahli media pembelajaran & $88,66 \%$ & Sangat baik \\
\hline 4 & Uji coba perorangan & $100 \%$ & Sangat baik \\
\hline 5 & Uji coba kelompok kecil & $97,5 \%$ & Sangat baik \\
\hline 6 & Uji lapangan / kelompok besar & $92,40 \%$ & Sangat baik \\
\hline \multicolumn{2}{|c|}{ Rata - rata } & $90,70 \%$ & Sangat baik \\
\hline
\end{tabular}

\section{Pembahasan}

Produk pengembangan media interaktif pembelajaran pada mata pelajaran pattern making merupakan materi pembelajaran yang telah dikembangkan dengan memperhatikan aspek pembelajaran dan media sebagai desain pesan pembelajaran .Penelitian pengembangan ini dilakukan untuk mengahasilkan suatu produk berupa $\mathrm{CD}$ pembelajaran media interaktif pattern making untuk kelas X SMK prodi tata busana yang bermanfaat untuk meningkatkan hasil belajar siswa. Proses penelitian ini diawali dari studi pendahuluan, pengumpulan bahan / materi pelajaran,membuat desain software, membuat dan memproduksi software, review dan uji coba produk yang divalidasi oleh ahli materi, ahli desain intruksional dan ahli media, melakukan analisis data, revisi produk sehingga layak digunakan oleh pengguna yaitu uji coba perorangan, kelompok kecil dan uji lapangan serta penilaian dari pengguna tersebut sehingga menghasilkan produk yang layak dan bermanfaat dalam pelaksanaan proses pembelajaran.

Revisi dilakukan berdasarkan atas penilaian,saran dan komentar dari para ahli materi, ahlidesain instruksional dan ahli media pembelajaran serta pengguna media tersebut yang bertujuan untuk menghasilkan produk media yang layak pakai.Variabel - variabel media pembelajaran memiliki nilai rata - rata sangat baik. Adapun variabel media pembelajaran yang dinilai meliputi kelayakan isi, penyajian, kebahasaan, pemrograman dan kegrafikan.

Dari hasil pengolahan data penelitian yang dilakukan terdapat perbedaan hasil belajar Pattern Making pada siswa yang menggunakan media interaktif dengan siswa yang dibelajarkan dengan media grafis, yaitu ratarata hasil belajar pattern making siswa yang dibelajarkan dengan media interaktif lebih tinggi dibandingkan dengan hasil belajar siswa yang menggunakan media grafis.Dari hasil pengujian menggunakan uji $t$ satu pihak, diperoleh harga $t_{\text {hitung }}=2,85$ dan $t_{\text {tabel }}: 2,00$. Jika dibandingkan maka $t_{\text {hitung }}>t_{\text {tabel }}$ atau $2,85>2,00$, dengan demikian dapat dinyatakan bahwa ada perbedaan hasil belajar dengan menggunakan media interaktif dengan siswa yang menggunakan media grafis. Hal ini dapat dilihat dari hasil nilai rata - rata Pattern Makingsiswa yang diajarkan dengan media interaktif yaitu sebesar 71,62( 62,47\%), 
sedangkan hasil nilai rata - rata Pattern Makingyang diajarkan dengan media grafis yaitu sebesar $62,87 \% \quad(53 \%)$. Data ini membuktikan bahwa penggunaan media pembelajaran interaktif lebih baik untuk meningkatkan pengetahuan siswa dalam pembelajaran Pattern Makingdari pada menggunakan media grafis.

Penggunaan media interaktif dalam pembelajaran Pattern Making siswa dapat berinteraksi langsung dan melakukan kontrol langsung pada sumber informasi, sehingga siswa dapat mengendalikan dan memperoleh apa yang dibutuhkan, misalnya mempelajari alat yang diperlukan, mengambil ukuran tubuh, mengidentifikasi ukuran yang akan di ukur, teknik mengukur tubuh dan membuat pola dasar teknik konstruksi yang telah disiapkan dalam bentuk animasi dan video. Siswa juga dapat berlatih menjawab soal/latihan yang telah dilengkapi denga balikan sehingga siswa dapat mengetahui kesalahan yang telah dilakukan dalam mengerjakan latihan. Media pembelajaran interaktif juga dilengkapi dengan rangkuman sehingga siswa dapat memperoleh ringkasan materi yang di sampaikan.

Pembelajaran dengan media interaktif juga membantu guru untuk mudah mengontrol sejauh mana materi yang sedang dipelajari siswa yang sesuai dengan karakter dan kemampuan yang berbeda - beda, sedangkan pembelajaran dengan media grafis siswa tidak berinteraksi langsung pada sumber informasi yang di dominasi oleh guru yang disampaikan secara klasikal. Pada soal - soal latihan siswa tidak langsung dapat memperoleh balikan dan akan menunggu dari guru. Guru menyampaikan materi pelajaran secara terstruktur dengan harapan materi pelajaran yang disampaikan dapat dikuasai dengan baik yang hanya berfokus pada kemampuan akademik siswa. Dengan demikian nilai keefektifan media interaktif lebih tinggi yaitu $71,62 \%$ dari nilai keefektifan pembelajaran dengan media grafis yaitu $62,87 \%$ yang menunjukkan bahwa terjadi perbedaan nilai sebesar $8,75 \%$. Dapat disimpulkan bahwa pembelajaran dengan menggunakan media interaktif dapat meningkatkan kompetensi dan pengetahuan siswa ,yang berarti media interaktif telah teruji.

Seels \& Galsgow seperti dikutip (Arsyad, 2002: 36) menyatakan media pembelajaran interaktif adalah suatu sistem penyampaian pengajaran yang menyajikan materi video rekaman dengan pengendalian komputer kepada siswa yang tidak hanya mendengar dan melihat video dan suara tetapi juga memberikan respon yang aktif dan respon itu yang menentukan kecepatan dan sekuensi penyajian. Media interaktif adalah suatu multimedia yang dilengkapi dengan alat pengontrol yang dapat dioperasikan oleh pengguna, sehingga pengguna dapat memilih apa yang dikehendaki untuk proses selanjutnya.

Hasil penelitian tentang pengembangan media pembelajaran interaktif berbasis komputer pada mata kuliah menggambar teknik oleh Basuki (2012) menyimpulkan bahwa hasil belajar mahasiswa yang dibelajarkan dengan menggunakan media pembelajaran interaktif berbasis multimedia lebih tinggi dari hasil belajar mahasiswa yang dibelajarkan dengan menggunakan media pembelajaran buku teks. Media pembelajaran interaktif memiliki keefektifan sebesar 80,46\% lebih tinggi dari keefektifan media pembelajaran buku teks sebesar $71,72 \%$

Hasil penelitian tentang pengembangan media pembelajaran interaktif dengan software program Macromedia Flash Professional 8.0 di SMA Sutomo 1 Medan pada mata pelajaran geografi oleh Lingin (2012: 101) menyatakan bahwa terdapat perbedaan yang signifikan antara hasil belajar siswa yang dibelajarkan dengan menggunakan media pembelajaran interaktif dengan hasil belajar siswa yang dibelajarkan dengan menggunakan cara konvensional.

Dengan digunakanya media pembelajaran interaktif ini pada mata pelajaran pattern making akan dapat memberikan dampak positif untuk meningkatkan hasil belajar siswa. Adapun kompetensi dasar yang dipelajari yaitu; teknik mengukur tubuh boneka jahit dan tubuh model serta membuat pola dasar teknik konstruksi.

\section{PENUTUP}

Berdasarkan rumusan, tujuan, hasil dan pembahasan penelitian pengembagan media interaktif yang dikemukakan pada bab sebelumnya maka dapat disimpulkan sebagai berikut :

1. Hasil validasi dari ahli materi, ahli desain intruksional, dan ahli media terhadap pengembangan media interaktif mata 
pelajaran pattern making yang dikembangkan dengan menggunakan Adobe Flash CS 6 menunjukkan bahwa keseluruhan aspek dengan rata-rata persentase $84,78 \%$ termasuk dalam kategori "Sangat Baik" dan ada beberapa yang harus direvisi kecil agar media tersebut layak digunakan untuk uji coba lapangan.

2. Hasil validasi dari uji coba perorangan, kelompok kecil dan uji coba lapangan terhadap pengembangan media interaktif mata pelajaran pattern making yang dikembangkan dengan menggunakan Adobe Flash CS 6 menunjukkan bahwa keseluruhan aspek dengan persentase ratarata $92,40 \%$ termasuk dalam kategori "Sangat Baik"

3. Dari hasil penilaiaan para ahli dan pengguna bahwa media interaktif yang dikembangkan peneliti layak digunakan sebagai media pembelajaran pattern making untuk kelas $\mathrm{X}$ Prodi Tata Busana.

4. Ada perbedaan hasil belajar siswa pada mata pelajaran Pattern Making dengan menggunakan media interaktif lebih tinggi dari hasil belajar siswa yang dibelajarkan dengan media grafis. Berarti Media Pembelajaran Interaktif pada mata palajaran pattern making dinyatakan telah teruji.

\section{DAFTAR PUSTAKA}

Arsyad, Azhar. (2011). MediaPembelajaran. Jakarta : Raja Grafindo Persada

Asyhar. Rayandra. (2012)Kreatif Mengembangkan Media

Pembelajaran.Jakarta: Rreferensi

Basuki, Nur. (2012) Pengembangan media pembelajaran interaktif berbasis komputer pada mata kuliah menggambar teknik. Medan : UNIMED

Budingsih, Annayanti. (2011) Sarana Belajar Kreatif dan Inovatif, Pembuatan Pola.Bogor : Bina Pustaka.

Cahyani, Firdawati.(2008). Pengembangan Media Interaktif Berbasis Komputerpada Materi Luas Permukaan Dan Volume Tabung Dan Kerucut Untuk Siswa Smp Kelas IX.Malang: UNM

Dahar, Ratna Wilis. (2011)Teori-teori belajara dan pembelajaran. Bandung : Erlangga

Danim. Sudarwan. (2008)Media Komunikasi Pendidikan. Jakarta : Bumi Aksara
Gerlach. V.S.and Ely,D.P .(1971)Teaching Media Systematic Approach. Engle wood Cliffs.Prentice Hall

Hamalik, Oemar. (2001) Proses Belajar Mengajar. Jakarta: Bumi Aksara

Heinich, R., et. al. (1996) Instructional Media and Technologies for Learning. New Jersey: Prentice Hall, Englewood Cliffs.

Hwie hoong, Njoo. (1998) Mengukur, Menggambar, memotong dan Menjahit Pakaian 1 dan 2. Semarang : Mandira

Konjo. Ian. (2013) Tesis Pembelajaran Dengan Power Point. Jakarta

Miarso. Yusufhadi. (2011) Menyemai Benih Teknologi Pendidikan.Jakarta. Kencana prenada media group

Muchith. Saekhan. (2008)Pembelajaran Kontektual. Semarang : Rasail

Muliawan, Porrie. (2003) Analisa Pecah Model Busana Wanita.Jakarta : BPK Gunung Mulia

Munadi. Yudhi.(2013). Media Pembelajaran Sebuah Pendekatan Baru. Jakarta :GP Press Group

Pagaribuan, Affandi Ferry. (2013) Pengembangan multimedia pembelajaran interaksi mata kuliah seni lukis I jurusan seni rupa fakultas bahasa dan seni. Medan. UNIMED

Program Pascasarjana UNIMED. (2010)Pedoman Administrasi dan Penulisan Tesis dan Desertasi. Medan: Unimed

Purwito, Anang. (2013)Tesis Pembelajaran Dengan Power Point . Sohogrup.

Romiszowski, A.J.(1988).The selection and use of instructional media: For improved classroom teaching and for interactive, individualized instruction. 2nd edition. $\mathrm{K}$. Page (London and New York)

Rusman. Kurniawan. Cepi. (2012)Pembelajaran Berbasis Teknologi Informasi dan Komunikasi. Jakarta: Raja Grafindo Persada

Seels, Barbara. Rita Richey. (1994)Teknologi Pembelajaran Definisi dan Kawasannya. Jakarta : UNJ

Sihite, Rimayanti. (2013)Pengembangan Multimedia Interaktif Pembelajaran Persamaan Reaksi Menggunakan Macromedia Flash 8 Untuk Siswa Sma N 5 Kota Jambi. Jambi : UNJA 
Soekarno.(2005) Buku Penuntun Membuat Pola Busana Tingkat Dasar.Jakarta : PT. Sun.

Sutopo, Ariesto Hadi. (2003) Multimedia Interaktif dengan Flash. Yogyakarta: Graha IlmuSumber :http://yahumairashazleen.blogspot.com/ 2012/12/model-pembelajaran-berbasismedia_2073.html

Sudjana.(2005) Metoda Statistika.Bandung : Tarsito

Suparman, Atwi. (2012). Desain Instruksional Modern. Jakarta : Erlangga

Sukardi. (2011)Metodologi Penelitian Pendidikan kompetensi dan Praktiknya. Jakarta : Bumi Aksara

Supriadi,D. (2002) Internet masuk sekolah:Pemberdayaan Guru dan Siswa dalam Era Sekolah berbasis E Learning.Bandung : PT Telkom

Syah, Muhibbin. (2004) Psikologi Pendidikan Dengan Pendekatan Baru.Bandung : Remaja Rosdakarya.

Syauqi, Khusni. (2012)Pengembangan Media Pembelajaran Modul Interaktif Las Busur Manual Di Smk Negeri 1 Sedayu. Yogyakarta : UNY

Trianto. (2010) Model pembelajaran terpadu: konsep, strategi, danImplementasinyadalam Kurikulum Tingkat Satuan Pendidikan (KTSP). Jakarta : Indonesia

Wena, Made. (2009) Strategi Pembelajaran Inovatif Kontemporer. Jakarta : Bumi Aksara 